EKONOMI POLITIK INSTITUSI ZAKAT: SATU PENELITIAN TERHADAP INSTITUSI ZAKAT DI PULAU PINANG

Mohammad Najwa

PRAKTIK KURBAN ONLINE DALAM PERSPEKTIF ISLAM TEBAR HEWAN KURBAN THK DI DOMPET DHUAFA

Reni Noviati

WAKAF SAHAM DITINJAU DARI HUKUM ISLAM DAN PERATURAN PERUNDANGUNDANGAN SETELAH BERLAKUNYA UNDANG-UNDANG NOMOR 41

TAHUN 2004 TENTANG WAKAF

Gusva Havita dan Gestivia Hakim

KARAKTERISTIK ENTREPRENEUR SYARIAH PADA USAHA MIKRO, KECIL, DAN MENENGAH (UMKM) DI BOGOR

Siti Usniah dan Anas Alhifni

ALTERNATIF SOLUSI ATAS PROBLEMATIKA PEMBIAYAAN MUDHARABAH

Rafidah

FAKTOR-FAKTOR YANG MEMPENGARUHI MOTIVASI MAHASISWA MENJADI ENTREPRENEUR SYARIAH

Nur Maulida Hidayat dan Anas Alhifni 
Ketua Editor :

Tuti Kurnia, SP., M.Si

Editor Pelaksana :

H. Sofian Muhlisin, LLB., LLM

Furqonul Haq, SEI., M.EI

Journal Manager :

Wildan Munawar, SEI

Jurnal Syarikah: Jurnal Ekonomi Islam adalah jurnal ilmiah yang diterbitkan untuk mendukung pengembangan ekonomi Islam. Jurnal Syarikah akan memuat artikelartikel yang terkait dengan kajian ekonomi Islam baik kajian teoritis maupun praktis. Redaksi menerima sumbangan artikel, tulisan ilmiah dari para peminat ilmiah kajian ekonomi dan keuangan syariah. Proses editing seperlunya tanpa mengubah maksud dan kandungan tulisan tersebut.

Alamat Redaksi :

Fakultas Ekonomi Islam

Universitas Djuanda Bogor

Gedung B Lantai 4

Jl. Tol Ciawi No.1 Ciawi Bogor Kode Pos 16720

Telp. (0251) 8240985

Email : fei@unida.ac.id 


\section{DAFTAR ISI}

EKONOMI POLITIK INSTITUSI ZAKAT: SATU PENELITIAN TERHADAP INSTITUSI ZAKAT DI PULAU PINANG

Mohammad Najwa

PRAKTIK KURBAN ONLINE DALAM PERSPEKTIF ISLAM TEBAR HEWAN KURBAN THK DI DOMPET DHUAFA

Reni Noviati

WAKAF SAHAM DITINJAU DARI HUKUM ISLAM DAN PERATURAN PERUNDANG-UNDANGAN SETELAH BERLAKUNYA UNDANG-UNDANG NOMOR 41 TAHUN 2004 TENTANG WAKAF

Gusva Havita, Gestivia Hakim

KARAKTERISTIK ENTREPRENEUR SYARIAH PADA USAHA MIKRO, KECIL DAN MENENGAH (UMKM) DI BOGOR

Siti Usniah, Anas Alhifni

ALTERNATIF SOLUSI ATAS PROBLEMATIKA PEMBIAYAAN MUDHARABAH

Rafidah

FAKTOR-FAKTOR YANG MEMPENGARUHI MOTIVASI MAHASISWA MENJADI ENTREPRENEUR SYARIAH

Nur Maulida Hidayat, Anas Alhifni 


\title{
FAKTOR-FAKTOR YANG MEMPENGARUHI MOTIVASI MAHASISWA MENJADI ENTREPRENEUR SYARIAH
}

\section{FACTORS AFFECTING THE MOTIVATION STUDENTS TO BE AN ENTREPRENEUR SHARIA}

\author{
N. M. Hidayat'ia; A. Alhifni² \\ 1aProgram Studi Ekonomi Islam Fakultas Ekonomi Islam Universitas Djuanda, Jl. Tol Ciawi \\ No. 1, Kotak Pos 35 Bogor 16720 \\ 2Program Studi Perbankan Syariah Fakultas Ekonomi Islam Universitas Djuanda, Jl. Tol \\ Ciawi No. 1, Kotak Pos 35 Bogor 16720
}

\begin{abstract}
This study aims to determine the factors that influence student motivation to become entrepreneurs sharia. The method used is descriptive quantitative approach and using analytical techniques is factor analysis. The object of research is the students of Islamic Economics in Bogor, by taking a sample of some students in the College of Public and Private, namely Institut Pertanian Bogor (IPB), University Juanda Bogor, University of Ibn Khaldun, and the College of Islamic Economics (STEI) Tazkia. The technique of collecting data using questionnaires deployment techniques. The results of this study indicate that factors a major factor and a contributing factor in influencing student motivation to be an entrepreneur sharia. The main factor is the attitude of honest, entrepreneurial training and special education. While supporting factors consists of creative, practice, course, responsible and experience.

Keywords: Factors, Student Motivation, Entrepreneur Sharia
\end{abstract}

\begin{abstract}
ABSTRAK
Penelitian ini bertujuan untuk mengetahui faktor-faktor yang mempengaruhi motivasi mahasiswa menjadi entrepreneur syariah. Metode penelitian yang digunakan adalah deskriptif dengan pendekatan kuantitatif dan menggunakan teknik analisis yaitu analisis faktor. Objek penelitiannya adalah mahasiswa Program Studi Ekonomi Islam di Bogor, dengan mengambil sampel dari beberapa mahasiswa yang ada di Perguruan Tinggi Negeri dan Swasta, yaitu Institut Pertanian Bogor (IPB), Universitas Djuanda Bogor, Universitas Ibn Khaldun, dan Sekolah Tinggi Ekonomi Islam (STEI) Tazkia. Teknik pengumpulan data menggunakan teknik penyebaran kuesioner. Hasil penelitian ini menunjukkan bahwa faktor-faktor yang menjadi faktor utama dan faktor pendukung dalam mempengaruhi motivasi mahasiswa menjadi entrepreneur syariah. Faktor utama tersebut adalah sikap jujur, pelatihan entrepreneur dan pendidikan khusus. Sedangkan faktor pendukung terdiri dari kreatif, praktik, mata kuliah, bertanggung jawab dan pengalaman.

Kata kunci: Faktor-faktor, Motivasi Mahasiswa, Enterpreneur Syariah
\end{abstract}

Hidayat, N. M. 2017. Faktor-Faktor yang Mempengaruhi Motivasi Mahasiswa Menjadi Entrepreneur Syariah. Jurnal Syarikah 3 (1): 403 - 418. 


\section{PENDAHULUAN}

Pengangguran di Indonesia terus bertambah setiap tahunnya, hal ini menjadi salah satu penyebab melemahnya pertumbuhan perekonomian Indonesia, tingginya pengangguran dapat mengakibatkan produktivitas dan pendapatan masyarakat akan berkurang, sehingga dapat menyebabkan timbulnya kemiskinan dan masalah-masalah sosial lainnya. Jumlah pengangguran yang terus bertambah disebabkan oleh lapangan pekerjaan yang terbatas dan persaingan dunia kerja yang semakin ketat, membuat lulusan universitas tidak terserap dengan baik di dunia kerja. Terdapat banyak faktor yang menyebabkan terus meningkatnya pengangguran, salah satu faktornya yaitu tidak sebandingnya jumlah angkatan kerja atau para pencari kerja dengan jumlah lapangan kerja yang mampu menyerapnya (Amalia, 2014: 175). Hal ini dibuktikan dengan data yang berasal dari Badan Pusat Statistik (BPS, 2016) menunjukkan bahwa jumlah pengangguran setiap tahunnya semakin meningkat, mulai dari lulusan SD, SLTP, SLTA, SMK, termasuk dari lulusan universitas yang setiap tahunnya terus bertambah. Jumlah pengangguran yang paling tinggi pada bulan Februari tahun 2016 adalah lulusan SLTA Umum/SMU meningkat dari tahun sebelumnya yaitu sekitar 1.546.699, lulusan SLTA Kejuruan/SMK yaitu sekitar 1.348.327, lulusan SLTP yaitu sekitar 1.313.815 dan lulusan SD yaitu sekitar 1.218.954 sedangkan untuk lulusan universitas tidak sebesar lulusan SMU tetapi mengalami peningkatan selama 3 tahun terakhir, di tahun 2016 merupakan jumlah tertinggi dari tahun sebelumnya.

Kementerian

Ketenagakerjaan mengatakan bahwa pemerintah terus mengoptimalkan penanggulangan pengangguran dan perluasan kesempatan kerja seperti kegiatan padat karya, Tenaga Kerja Mandiri (TKM), Terapan Teknologi Tepat Guna (TTG) dan Tenaga Kerja Sukarela (TKS), job fair dan bursa kerja online, serta pelayanan dalam rangka penempatan dan pelindungan tenaga kerja luar negeri. Selain itu, juga menciptakan program pelatihan dan pemberian bantuan sarana usaha kepada kelompok masyarakat dan pengembangan entrepreneur (Ahmad, 2016: 1). Salah satu yang masih diharapkan dari pemerintah adalah mendorong iklim usaha yang baik agar bisa menggugah keinginan untuk menjadi entrepreneur terutama bagi para lulusan universitas yang masih menganggur atau mendorong semangat entrepreneur melalui berbagai kementerian terutama Kementerian Pendidikan dan kebudayaan, dengan memasukan kurikulum mengenai entrepreneur pada tingkat universitas (Saputra \& Susena, 2013: 41-42).

Berdasarkan hal tersebut, maka lulusan universitas diharapkan untuk dapat menciptakan lapangan pekerjaan. Maka dari itu, sangat penting mahasiswa untuk dapat mampu menciptakan lapangan pekerjaan, yaitu dengan menjadi seorang entrepreneur. Pentingnya entrepreneur tidak hanya sebagai alat untuk melakukan perbaikan dan perubahan di dalam kualitas hidup diri dan masyarakat, tetapi entrepreneur juga dibuktikan dapat berperan signifikan di dalam mewujudkan kualitas diri masyarakat dan bangsa (Frinces, 2010: 36).

Jiwa entrepreneur tidak muncul dengan sendirinya melainkan harus dibangun dalam sebuah sistem, yaitu dengan memperkenalkan entrepreneurship dalam perkuliahan, seminar-seminar mengenai 
entrepreneurship ataupun pelatihan khusus untuk membangun jiwa entrepreneurship mahasiswa, yaitu dengan menumbuhkan wawasan untuk melakukan entrepreneur, menumbuhkan mental dan semangat entrepreneur, menumbuhkan semangat membangun bisnis yang beretika dan meningkatkan motivasi mahasiswa dalam melakukan entrepreneur. (Saputra \& Susena, 2013: 41). Adapun langkahlangkah yang dapat dilakukan dalam menciptakan entrepreneur di tingkat universitas yaitu: memasukan kurikulum entrepreneurship dalam kurikulum pendidikan, memasukan mata kuliah entrepreneurship ke dalam kurikulum, mendirikan laboratorium entrepreneurship syariah, mengadakan pelatihan-pelatihan entrepreneurship, memberikan dukungan bagi entrepreneur muda dengan memberikan bantuan dana lunak, serta entrepreneurship nyata (Nuriasari, 2013: 16-17).

Peranan universitas dalam memotivasi lulusan menjadi seorang entrepreneur sangat penting dalam menumbuhkan jumlah entrepreneur. Dengan meningkatnya jumlah entrepreneur dari lulusan universitas akan mengurangi pertambahan jumlah pengangguran bahkan akan menambah jumlah lapangan pekerjaan (Endratno \& Widhiandono, 2014: 70).

Faktor-faktor yang mungkin dapat mempengaruhi motivasi mahasiswa menjadi entrepreneur, yaitu pengaruh dari pendidikan yang pernah diterima oleh mahasiswa, karakter mahasiswa tersebut apakah memiliki karakteristik untuk dapat menjadi entrepreneur, serta keahlian yang dimiliki oleh mahasiswa tersebut, apakah memiliki keahlian khusus untuk dapat dijadikan sebagai modal melakukan entrepreneur. Oleh karena itu, penulis ingin melakukan penelitian dengan judul "Faktor-faktor yang Mempengaruhi Motivasi Mahasiswa Menjadi Entrepreneur Syariah".

\section{MATERI DAN METODE}

Entrepreneur adalah orang yang menciptakan kerja bagi orang lain dengan cara mendirian, mengembangkan, dan melembagakan perusahaan miliknya sendiri dan bersedia mengambil resiko pribadi dalam menemukan peluang berusaha dan secara kreatif menggunakan potensi-potensi dirinya untuk mengenali produk, mengelola dan menentukan cara produksi, menyusun operasi untuk pengadaan produk, memasarkannya serta mengatur permodalan operasinya (Mandiangan \& Yulina, 2012: 3)

Entrepreneur dalam pandangan Islam adalah seseorang yang mampu mengeksplorasi faktor-faktor produksi dengan berpijak pada syariat Islam dalam koridor etika bisnis Islami dengan mampu memproduksi produk baik pemikiran, barang ataupun jasa untuk dikonsumsi konsumen dengan prinsip halalan thoyyiban, baik dari segi kehalalan zatnya dan kehalalan selain zatnya, dimana tujuan dari bisnis seorang entrepreneur bukan hanya mengejar profit tetapi juga mengejar manfaat dengan menjauhi hal-hal yang dilarang dalam Islam (Cahyani, 2015: 203), sebagai mana hadist berikut:

"Berusaha untuk mendapatkan penghasilan halal merupakan suatu kewajiban, di samping tugas-tugas lain yang diwajibkan" (HR. Baihaki)

Karakteristik

entrepreneur

(Cahyaningrum, Setyawan, Hari, \& Ainuddi, 2013: 3; Aprijon, 2013: 4), meliputi :

1. Percaya diri,

2. Berorientasi tugas dan hasil, 
3. Berani mengambil resiko dan menyukai tantangan,

4. Kepemimpinan,

5. Keorisinilan, dan

6. Berorientasi pada masa depan.

Selain itu, adapun karakteristik kewirausahaan yang dipaparkan oleh Santoso yaitu (Santoso, 2014: 11):

1. Karakteristik Demografi

2. Karakteristik Individu

3. Sifat Personal

4. Orientasi pada Kewirausahaan

5. Kesiapan Kewirausahaan, rasa percaya diri

Sedangkan menurut Antoni (2014: 345) dalam penelitiannya mengatakan bahwa karakter entrepreneur syariah terdiri dari:

1. Takwa sebagai kerangka kerja

2. Ibadah kepada Allah SWT adalah prioritas

3. Halal sebagai prioritas

4. Tidak boros menggunakan sumber daya

5. Terpercaya

6. Konsentrasi terhadap kesejahteraan

7. Berpengetahuan luas

8. Peduli terhadap lingkungan social

Motivasi adalah kemauan dan keinginan kuat seseorang untuk berperilaku. Semakin besar motivasi seseorang terhadap sesuatu, maka makin tinggi seseorang untuk berperilaku mewujudkan keinginannya. Selain itu, motivasi juga merupakan dorongan yang muncul dari dalam diri seseorang untuk melakukan suatu kegiatan (Jati, 2009: 146; Handayani \& Suyanto, 2016: 96)

Motivasi seseorang dipengaruhi oleh 2 (dua) faktor, yaitu (Muchlas, 2012: 1-2; Haryani \& Tairas, 2014: 35):

a. Faktor Internal, yaitu faktor yang berasal dari dalam diri individu, tediri dari: Persepsi individu mengenai diri sendiri, harga diri dan prestasi, harapan, kebutuhan, serta kepuasan.

b. Faktor Eksternal, yaitu faktor yang berasal dari luar diri individu, terdiri dari: Jenis dan sifat pekerjaan, kelompok kerja, kondisi lingkungan, serta sistem imbalan yang diterima.

Terdapat beberapa faktor yang memotivasi mahasiwa untuk berkeinginan menjadi entrepreneur, yaitu (Tama, 2010: 104-105):

1. Keberhasilan diri dalam entrepreneur

Keberhasilan diri dalam entrepreneur merupakan pencapaian suatu tujuan usaha yang telah ditentukan, keberhasilan diri dapat ditentukan dengan usaha yang dilaksanakan untuk meraih keberhasilan itu sendiri.

2. Toleransi akan resiko

Pengambilan keputusan seseorang dalam melakukan kegiatan entrepreneur sebaiknya mempertimbangkan tingkat toleransi akan adanya resiko (Tama, 2010: 49). Resiko merupakan kemungkinan terjadinya suatu hal yang tidak kita inginkan pada waktu yang akan datang, sebagai akibat yang kita ambil. Toleransi akan resiko berkaitan dengan kemampuan, kreativitas dalam menyelesaikan besar kecilnya resiko yang diambil untuk mendapatkan penghasilan yang diharapkan. Semakin tingginya resiko yang diambil, maka semakin besar pula penghasilan yang akan diraih.

3. Kebebasan dalam bekerja

Kebebasan dalam bekerja merupakan model kerja dimana seseorang melakukan pekerjaannya untuk dirinya sendiri dan tidak berkomitmen untuk bekerja dibawah 
kaki tangan atasannya pada jangka waktu tertentu.

Selain itu, terdapat beberapa faktor yang mendorong seseorang entrepreneur adalah (Alma \& Priansa, 2014: 136) :

1. Individu (Personal)

Menyangkut aspek-aspek kepribadian yang ada pada diri seseorang, misalnya orang rajin, pekerja keras, percaya diri, dapat dipercaya/jujur, mudah bergaul dengan orang lain, dan sebagainya.

2. Sosiologis (Sociological)

Adanya partisipasi dari keluarga, keluarga mau membantu dan sangat mendukung kegiatan entrepreneur.

3. Lingkungan (Environmental)

Adanya lingkungan yang kondusif, lingkungan yang dapat dijadikan contoh dan tempat belajar, mencari pengalaman dalam berbisnis.

Variabel Pendidikan, Kepribadian dan Keahlian

1. Pendidikan

Entrepreneur dapat diperkenalkan dan dilatih dengan beberapa cara, salah satunya dalam bidang pendidikan, dapat diajarkan melalui mata kuliah kewirausahaan, pelatihan khusus mengenai entrepreneur, seminar entrepreneurship, serta praktik langsung melaksanakan kegiatan entrepreneur sampai diikutsertakan lomba agar terlatih dan belajar menghadapi para pesaing. Pendidikan entrepreneur merupakan pendidikan dan pemahaman dasar yang memungkinkan mahasiswa untuk mengembangkan dan menggunakan kreativitas, mengambil inisiatif, tanggung jawab dan belajar mengambil resiko serta menghadapi resiko. Pendidikan entrepreneur diawali dengan pembentukan pola pikir entrepreneur dilanjutkan dengan pembentukan perilaku kreatif dan inovatif agar dapat berkreasi (Aprilianty, 2012: 313; Susilaningsih, 2015: 4; Atmaja \& Margunani, 2016: 783).

Tujuan pendidikan disini adalah untuk mewujudkan pribadi-pribadi yang mampu menolong diri sendiri serta orang lain, sehingga dapat terwujud kehidupan yang sejahtera. Pendidikan yang dimaksud dalam hal ini adalah pendidikan kewirausahaan untuk membentuk jiwa entrepreneur pada mahasiswa, sehingga mahasiswa mahasiswa dapat mengahadapi permasahalahan kehidupan yang wajar, kreatif, mandiri dan tidak bergantung kepada orang lain (Safitri \& Rustiaba, 2016: 891).

2. Kepribadian

Kepribadian dalam Kamus Besar Bahasa Indonesia (KBBI) berarti sifat yang tercermin pada sikap seseorang yang membedakannya dengan orang lain. Kepribadian dapat mempengaruhi seseorang dalam melakukan suatu kegiatan, seperti dalam menerima pekerjaan, seseorang yang memiliki kepribadian bertanggung jawab, ia akan menyelesaikan pekerjaannya sampai selesai dan akan mempertanggung jawabkan apa yang telah ia kerjakan, begitupun dalam melakukan kegiatan entrepreneur.

Entrepreneur yang berhasil memiliki kepribadian yang unggul sehingga memiliki kreativitas yang tinggi serta memiliki keberanian yang besar dalam mengambil resiko. Kepribadian merupakan sifat dasar yang dimiliki seseorang yang membedakannya dengan orang lain. Semakin banyak yang memiliki potensi kepribadian entrepreneur, maka akan semakin 
banyak yang berminat melakukan kegiatan entrepreneur dan siap menjalankan proses entrepreneur. Hal ini menunjukkan bahwa potensi kepribadian entrepreneur harus dibangun, seperti membantu mahasiswa agar menumbuhkan dan membangun potensi diri (Aprilianty, 2012: 322).

3. Keahlian

Keahlian (skill) merupakan kemahiran seseorang pada suatu ilmu atau suatu bidang tertentu, dengan memiliki keahlian, seseorang akan memiliki kemampuan untuk mengatasi permasalahan dalam menyelesaikan suatu pekerjaan. Keahlian tidak dimiliki oleh semua orang, oleh sebab itu keahlian dapat dibentuk dengan mengikuti kursus, pelatihan serta mempelajari ilmu pada bidang tertentu, seperti mempelajari cara-cara memasak, agar nantinya dapat membuka rumah makan, sehingga dapat membuka lapangan pekerjaan dengan memanfaatkan keahlian yang dimiliki (Fefianti \& Sujianto, 2013: 108).

Keahlian juga dapat dimiliki melalui pengalaman. Pengalaman dapat dibangun dengan meningkatkan pengetahuan melalui pendalaman pekerjaan, mampu menghadapi kesulitan pekerjaan, dengan sendirinya akan meningkatkan keahlian yang dimiliki.

Selain pendidikan dan kepribadian, seorang entrepreneur juga dapat terdorong untuk melakukan kegiatan entrepreneur yaitu dengan keahlian yang dimiliki dirinya. Keahlian merupakan minat atau bakat yang dimiliki oleh seseorang. Keahlian yang dimiliki memungkinkan untuk dapat menjelaskan dan menyelesaikan tugastugas secara baik dengan hasil yang maksimal. Keahlian yang dimiliki seseorang dapat diperoleh dari pendidikan formal maupun non formal. Ketika seseorang memiliki keahlian khusus dibidang tertentu, maka akan memudahkan seseorang untuk menjalankan kegiatan entrepreneur pada keahlian yang dimilikinya (Alma \& Priansa, 2014: 137).

Keahlian dalam kewirausahaan merupakan keahlian dan kemampuan usaha untuk mendirikan dan mengembangkan berbagai kegiatan usaha (Sugiarto, Herlambang, Brastono, Sudjana, \& Kelana, 2007: 18)

\section{Metode Penelitian}

Penelitian ini adalah penelitian deskriptif kuantitatif. Sumber data pada penelitian ini terbagi menjadi dua bagian, yaitu:

1. Data primer adalah data yang dapat diperoleh secara langsung dari sumber yang bersangkutan. Dalam penelitian ini, data yang diperoleh melalui kuesioner yang disebar kepada responden.

2. Data sekunder adalah data yang diperoleh dari hasil olahan data primer. Data sekunder berfungsi sebagai data pendukung dari data primer. Pada penelitian ini data sekunder diambil dari jurnal, buku-buku, artikel dan litelatur yang berkaitan dengan penelitian ini.

Populasi dari penelitian ini adalah seluruh mahasiswa program studi Ekonomi Islam yang ada di Bogor yang berjumlah 735 mahasiswa, yang terdiri dari Universitas Djuanda Bogor, Institut Pertanian Bogor, Universitas Ibn Khaldun, dan Sekolah Tinggi Ekonomi Islam Tazkia. Sampel dalam penelitian ini sebanyak 100 
mahasiswa. Penentuan jumlah sampel menggunakan Slovin dengan rumus: $\mathrm{n}=$ $\mathrm{N} / 1+\mathrm{N} . \mathrm{e}^{2}$

Penelitian ini memiliki responden sebanyak 100 mahasiswa, dengan penyebaran kuesioner. Sebelum melakukan penyebaran kuesioner, terlebih dahulu perlu dilakukan pengujian dengan uji validitas dan reliabilitas. Uji validitas dan reliabilitas. Uji validitas dalam penelitian ini menggunakan metode korelasi product moment atau pengujian dengan cara mengorelasikan skor butir pada setiap pertayaan dan pernyataan pada kuesioner dengan skor totalnya. Rumus metode korelasi product moment adalah:

$$
=\frac{\frac{\sum x y-\left\{\sum x\right\}\{y\}}{N}}{\sqrt{\left\{\frac{\sum x^{2}-\left(\sum x\right)^{2}}{N}\right\}\left\{\frac{\sum y^{2}-\left(\sum y\right)^{2}}{N}\right\}}}
$$

Keterangan:

rxy : koefisien korelasi antara $\mathrm{x}$ dan y $r_{x y}$

$\mathrm{N} \quad$ : Jumlah responden

$\mathrm{X}$ : Skor item

$\mathrm{Y} \quad$ : Skor total

$\sum \mathrm{X} \quad$ : Jumlah skor item

$\sum \mathrm{Y} \quad$ : Jumlah skor total

$\sum \mathrm{X}^{2} \quad$ : Jumlah kuadrat skor item

$\sum \mathrm{Y}^{2}$ : Jumlah kuadrat skor total

Setelah uji validitas, dilakukan uji reliabilitas dengan menggunaan rumus Cronbach's Alpha yaitu sebagai berikut:

$$
r_{11}=\frac{k}{k-1} \times\left\{1-\frac{\sum S_{i}}{S_{t}}\right\}
$$

Keterangan:

$\mathrm{r}_{11} \quad=$ Nilai reliabilitas

$\sum \mathrm{S}_{\mathrm{i}} \quad=$ Jumlah varians skor tiap-tiap item

$\mathrm{S}_{\mathrm{t}} \quad=$ Varians total

$\mathrm{k}=$ Jumlah item
Skala Likert adalah skala yang digunakan untuk mengukur sikap, pendapat dan persepsi seseorang atau sekelompok orang tentang fenomena sosial (Sugiono, 2013: 136). Dengan menggunakan skala likert, variabel yang diukur dijabarkan dari variabel menjadi dimensi, dari dimensi dijabarkan menjadi indikator, serta indikator dijabarkan menjadi subindikator yang dapat diukur. Sehingga subindikator dapat dijadikan tolak ukur untuk membantu suatu pertanyaan atau pernyataan yang perlu dijawab oleh responden. Dalam penelitian ini pernyataan yang ada diberikan skor dari 4, 3, 2, 1. Pengukurannya sendiri terdiri atas:
a. Sangat setuju (SS)
$=4$
b. Setuju (S)
$=3$
c. Tidak Setuju
$=2$
d. Sangat Tidak Setuju
$=1$

Crosstab digunakan untuk menyajikan data categorical dalam bentuk tabulasi yang terdiri dari baris (row) dan kolom (column). Dalam penelitian ini, Crosstab digunakan untuk menjawab pertanyaan penelitian pertama, yaitu karakterisitik mahasiswa yang seperti apa yang termotivasi menjadi entrepreneur syariah. Sehingga dapat menunjukkan karakter responden yang termotivasi menjadi entrepreneur syariah.

Untuk mengetahui faktor-faktor yang menjadi faktor utama dan faktor pendukung yang mempengaruhi motivasi mahasiswa menjadi entrepreneur syariah dengan menggunakan analisis faktor. Analisis faktor didefinisikan sebagai salah satu bentuk analisis multivariat yang memiliki fungsi untuk menemukan satu atau beberapa variabel (Munawar, 2016:154). Analisis faktor tersebut diuji terlebih dahulu dengan menggunakan uji 
Kaiser Mayer Olkin (KMO). Uji KMO digunakan untuk menunjukkan apakah metode sampling yang digunakan memenuhi syarat kecukupan data dan mengukur kecukupan sampel secara menyeluruh atau tidak.

Dalam penelitian ini, faktor-faktor yang mungkin menjadi indikator dalam mempengaruhi motivasi mahasiswa menjadi entrepreneur syariah meliputi 3 variabel, yaitu Pendidikan $\left(\mathrm{F}_{1}\right)$, karakter $\left(F_{2}\right)$ dan Keahlian $\left(F_{3}\right)$. Dari ketiga variabel masing-masing memiliki beberapa indikator, yaitu:

a. $\mathrm{F}_{1}$ (Pendidikan) memiliki indikator mata kuliah entrepreneur $\left(\mathrm{X}_{1}\right)$, pelatihan entrepreneur $\left(\mathrm{X}_{2}\right)$, seminar entrepreneur $\left(\mathrm{X}_{3}\right)$, praktik melakukan kegiatan entrepreneur $\left(\mathrm{X}_{4}\right)$.

b. $\mathrm{F}_{2}$ (Karakter), memiliki variabel Bertanggung jawab $\left(\mathrm{X}_{1}\right)$, Jujur $\left(\mathrm{X}_{2}\right)$, Kreatif $\left(\mathrm{X}_{3}\right)$

c. $\mathrm{F}_{3}$ (Keahlian), memiliki variabel pendidikan khusus $\left(\mathrm{X}_{1}\right)$, pengalaman $\left(\mathrm{X}_{2}\right)$

Maka dari ketiga faktor tersebut, dapat dirumuskan dalam model matematis, yaitu: Pendidikan $=\mathrm{a}_{11}$ (mata kuliah entrepreneur) $+\mathrm{a}_{12}$ (pelatihan entrepreneur) $+\mathrm{a}_{13}$ (praktik melakukan kegiatan entrepreneur)

Karakter $=\mathrm{a}_{21}$ (bertanggung jawab) $+\mathrm{a}_{22}$ (jujur) + a 23 (kreatif)

Keahlian $=\mathrm{a}_{31}$ (pendidikan khusus) $+\mathrm{a}_{32}$ (pengalaman)

\section{HASIL DAN PEMBAHASAN}

\section{Faktor-faktor yang mempengaruhi motivasi mahasiswa menjadi Entrepreneur syariah}

Berdasarkan penelitian yang dilakukan melalui penyebaran kuesioner kepada 100 responden, dapat diketahui bahwa yang berjenis kelamin laki-laki sebesar 23\% (23 responden) dan perempuan sebesar $77 \%$ (77 responden). Jumlah responden perempuan lebih banyak dibandingkan dengan responden laki-laki, hal ini dikarenakan jumlah mahasiswa program studi Ekonomi Islam di Bogor lebih banyak dibanding mahasiswa laki-laki, serta teknik pengambilan sampel menggunakan random sampling.

Usia dari 100 responden dapat diketahui bahwa responden yang berusia 17-20 tahun sebanyak 54 orang (54\%), yang berusia 21-25 tahun sebanyak 46 orang (46 \%). Sehingga berdasarkan sampel yang didapat dalam penelitian ini responden yang mendominasi adalah yang berusia 17-20 tahun. Sehingga dari hasil penelitian ini peneliti dapat memberikan gambaran mengenai karakteristik berdasarkan usia responden bahwa responden yang paling dominan adalah yang berusia 17 sampai dengan 20 tahun.

Asal universitas yang menjadi responden pada penelitian ini terdiri dari mahasiswa program studi Ekonomi Islam Universitas Djuanda Bogor sebanyak 25 orang (25\%), mahasiswa program studi Ekonom Islam Institut Pertanian Bogor sebanyak 41 orang (41\%), mahasiswa program studi Ekonomi Islam Universitas Ibn Khaldun sebanyak 9 orang (9\%), dan mahasiswa program studi Ekonomi Islam STEI Tazkia sebanyak 25 orang (25\%). Penentuan jumlah responden didasarkan pada banyaknya jumlah mahasiswa Ekonomi Islam yang ada di masing-masing universitas.

Semester dari 100 mahasiswa Ekonomi Islam di Bogor dapat diketahui bahwa mahasiswa semester 2 sebanyak 3 orang (3 $\%$ ), mahasiswa semester 4 sebanyak 34 orang (34\%), mahasiswa semester 6 sebanyak 41 orang (41\%), dan mahasiswa semester 8 sebanyak 22 orang (22 \%). 
Sehingga dari hasil tersebut dapat memberikan gambaran mengenai karakteristik mahasiswa program studi ekonomi Islam di Bogor berdasarkan semester, dimana dalam penelitian ini yang paling dominan adalah mahasiswa semester 6 dengan persentase $41 \%$. Sedangkan yang paling sedikit adalah mahasiswa semester 2 dengan persentase $3 \%$. Sehingga berdasarkan sampel yang didapat dalam penelitian ini responden yang mendominasi adalah mahasiswa semester 6 karena pada semester tersebut mahasiswa telah mengikuti beberapa pendidikan mengenai entrepreneur.

Mata kuliah yang pernah diambil dari 100 responden, yaitu mahasiswa yang pernah mengambil mata kuliah terkait entrepreneur dalam bentuk teori saja sebanyak 29 orang (29\%), mahasiswa yang pernah mengambil mata kuliah terkait entrepreneur dalam bentuk teori dan praktik sebanyak 70 orang (70\%), dan mahasiswa yang pernah mengambil mata kuliah entrepreneur dalam bentuk lainnya hanya 1 orang (1\%). Sehingga dari hasil tersebut, penulis dapat memberikan gambaran mengenai karakteristik mata kuliah yang pernah diambil, dimana dalam penelitian ini yang paling dominan adalah teori dan praktik dengan persentase $70 \%$, hal ini karena responden yang paling banyak pada mahasiswa semester 6, sehingga mahasiswa sudah menerima mata kuliah yang berkaitan dengan entrepreneur seperti mata kuliah kewirausahaan Islam, entrepreneurship, kewirausahaan dan bisnis Islam, ekonomi koperasi dan UMKM, entrepreneurship dan inovasi bisnis, dan simulasi bisnis. Serta telah mempraktikannya, baik sebagai tugas yang ditugaskan dosen maupun praktik yang dilakukan sebagai bisnis yang dijalankan mahasiswa.
Motivasi dari 100 responden, dapat diketahui bahwa mayoritas mahasiswa program Studi Ekonomi Islam di Bogor memiliki motivasi yang tinggi untuk menjadi seorang entrepreneur syariah yaitu sekitar 97 mahasiswa (97\%), yang terdiri dari 25 mahasiswa (25\%) dari Universitas Djuanda Bogor, 41 mahasiswa (41 \%) dari Institut Pertanian Bogor, 7 mahasiswa (7 \%) dari Universitas Ibn Khaldun dan 24 mahasiswa (24\%) dari STEI Tazkia. Sedangkan mahasiswa yang memiliki motivasi rendah untuk menjadi seorang entrepreneur syariah sekitar 3 mahasiswa (3\%), yang terdiri dari 2 mahasiswa (2\%) yang berasal dari Ibn Khaldun dan 1 mahasiswa (1 \%) yang berasal dari STEI Tazkia Bogor.

\section{Uji Reliabilitas dan Validitas}

Uji reliabilitas digunakan untuk mengetahui sejauh mana instrumen pengukuran dapat dipercaya dan memberikan hasil yang konsisten. Uji reliabilitas dari masing-masing instrumen pengukuran menggunakan uji cronbach's alpha. Kuesioner dikatakan reliabilitas apabila nilai koefisien alpha lebih besar dari 0,5 $(\alpha>0,5)$. Hasil uji dari semua pernyataan adalah 0,945. Dengan demikian, maka instrumen yang digunakan dalam penelitian cukup baik dalam mengukur responden terhadap variabel yang diteliti dan dapat dilanjutkan ke tahap selanjutnya.

Sedangkan uji validitas dari semua pernyataan ini berjumlah 72 pernyataan, pernyataan dikatakan valid apabila nilai Corrected Item Total Correlation > 0,213. Sehingga pernyataan yang dinyatakan lolos uji validitas sebanyak 67 pernyataan dan 5 pernyataan inyatakan tidak lolos karena nilai Corrected Item Total Correlation < 0,213 . 


\section{Analisis Faktor}

Dalam penelitian ini dilakukan menggunakan 4 variabel dengan 10 indikator disebar pada 82 pertanyaan dan pernyataan yang mengarahkan responden pada variabel mana yang menjadi faktor yang mempengaruhi motivasi mahasiswa menjadi entrepreneur syariah khususnya pada mahasiswa program studi Ekonomi Islam di Bogor. Kuesioner ini menggunakan skala likert dengan skor paling tinggi adalah 4 dan skor paling rendah adalah 1 dengan jumlah responden sebanyak 100 orang. Untuk lebih jelasnya dapat dilihat tahapan-tahapan berikut ini:

\section{Uji Kaiser Mayer Olkin (KMO)}

Langkah awal yang dilakukan dalam pengolahan analisis faktor adalah menilai indikator dan variabel yang dianggap layak dan telah diuji validitasnya untuk dimasukan dalam analisis selanjutnya. Uji Kaiser Mayer Olkin (KMO) digunakan untuk menunjukkan apakah metode sampling yang digunakan memenuhi syarat kecukupan data dan mengukur kecukupan sampel secara menyeluruh atau tidak. Batas nilai KMO adalah 0,5, sehingga nilai KMO harus lebih besar dari 0,5 agar dapat dianalisis lebih lanjut. Dari hasil pengolahan data dengan program SPSS 22 diperoleh output hasil pengolahan angka Kaiser Mayer Olkin Measure of Sampling Adequeacy (KMO-MSA) mencapai 0,865. Hal ini termasuk hasil kategori baik mengingat angka KMO-MSA telah melebihi batas nilai KMO yaitu 0,5. Sehingga nlai KMO 0,865 > 0,5. Adapun nilai bartlett's of sphericity mempunyai nilai 406,120 dengan nilai signifikansi 0,000 . Nilai ini berarti bahwa faktor pembentuk variabel sudah baik dan bisa dianalisis lebih lanjut.

\section{Proses Ekstraksi}

Proses ekstraksi merupakan proses inti dari analisis faktor, yaitu melakukan ekstraksi terhadap sekumpulan variabel yang telah lolos pada uji validitas sebelumnya, sehingga terbentuk satu atau lebih faktor. Pada proses ekstraksi faktor ini menggunakan IBM SPSS 22 dengan metode ekstraksi principal Component Analysis (PCA), dengan tingkat eigenvalues over $=1$, yang artinya item dengan angka eigenvalues di bawah 1 akan dikeluarkan.

Hasil penelitian menunjukkan bahwa variabel yang memiliki nilai extraction tertinggi adalah variabel motivasi sebesar 0,799 . Hal ini berarti $79,9 \%$ varian variabel akan terbentuk. Kemudian variabel kreatif sebesar 74,3\%, jujur sebesar 72,1\%, pelatihan sebesar $66,6 \%$, pelatihan khusus sebesar $60,9 \%$, bertanggung jawab sebesar $58,7 \%$, pengalaman sebesar 49,4\%, seminar sebesar 45,9\%, praktik sebesar $40,8 \%$ dan variabel yang memiliki nilai terendah adalah variabel mata kuliah 0.407. Hal ini berarti $40,7 \%$ varian dari variabel mata kuliah dapat dijelaskan oleh faktor yang akan terbentuk. Semakin besar nilai communaities suatu variabel menunjukkan semain kuat hubungan dengan faktor yang nantinya akan terbentuk.

Selanjutnya, berdasarkan pengolahan data dengan SPSS 22 didapatkan hasil bahwa 10 indikator yang digunakan dalam penelitian ini akan dikelompokkan ke dalam 2 faktor, yaitu:

Faktor pertama memiliki nilai eigenvalue sebesar 4,719 dengan varian 47,193\%. Faktor kedua yang memiliki nilai eigenvalue sebesar 1,173 dengan varian $11,730 \%$.

Hasil tersebut menunjukkan bahwa faktor 1 mampu menjelaskan seluruh varians sebesar 47,193\% dan faktor kedua menjelaskan seluruh varians sebesar 11,730\%. Sedangkan berdasarkan kumulatif seluruh faktor dapat 
menjelaskan varians sebesar 58,923\%. Hal ini berarti masih terdapat variabel-variabel lain yang menjadi indikator yang dapat mempengaruhi motivasi mahasiswa menjadi entrepreneur syariah.

Setelah mendapatkan 2 faktor yang memiliki jumlah paling optimas, maka analisis selanjutnya yang perlu dilakukan adalah pada component matrix merupakan factor of loading yang menunjukkan besar korelasi tiap baris yang didasarkan pada angka mutllak factor of loading yang diberikan setiap variabel terhadap masingmasing faktor.

Berdasarkan nilai component matrix terlihat bahwasannya keseluruhan variabel berapa pada faktor 1 dengan nilai factor of loading setiap variabel pada faktor 1 lebih besar dibandingkan nilai factor of loading pada faktor 2. Maka dari itu, perlu adanya proses rotasi agar component 2 memiliki nilai factor of loading yang besar., sehingga dapat terlihat variabel mana yang masuk pada component 1 dan component 2. Proses rotasi dalam penelitian ini menggunakan metode varimax yang bertujuan untuk memperbesar nilai loading of factor yang sebelumnya bernilai kecil.

Setelah dilakukkan rotasi, maka akan lebih mudah menentukan variabel-variabel mana yang akan masuk kedalam kedua faktor tersebut. Dari hasil rotated component matrix dapat dilihat bahwa variabel yang termasuk kedalam component 1 yaitu indikator jujur $(0,848)$, pelatihan $(0,788)$, pendidikan khusus $(0,720)$ dan seminar $(0,552)$. Hal ini berarti bahwa indikator tersebut mempunyai korelasi yang tinggi terhadp faktor 1 . Kemudian untuk component 2 yaitu indikator motivasi $(0,894)$, kreatif $(0,680)$, praktik $(0,616)$, mata kuliah $(0,600)$, bertanggung jawab $(0,598)$ dan pengalaman $(0,502)$.
Hasil analisis faktor dengan 10 indikator yang diteliti menggunakan metode ekstraksi principle component analysis yang direduksi menjadi 2 faktor dimana indkator jujur, pelatihan, pendidikan khusus dan seminar masuk kepada faktor 1. Sedangkan motivasi, kreatif, praktik, mata kuliah, bertanggung jawab dan pengalaman masuk kepada faktor 2. Hasil rincian dari analisis faktor dapat dilihat pada tabel berikut:

\section{Tabel 1.}

\section{Faktor-Faktor yang Mempengaruhi \\ Motivasi Mahasiswa Menjadi \\ Entrepreneur Syariah}

\begin{tabular}{|c|c|c|c|c|}
\hline $\begin{array}{c}\text { Fakt } \\
\text { or }\end{array}$ & $\begin{array}{c}\text { Variabel } \\
\text { Asal }\end{array}$ & $\begin{array}{c}\text { Nilai } \\
\text { Factor } \\
\text { of } \\
\text { Loadin } \\
g\end{array}$ & $\begin{array}{c}\text { Eigenval } \\
\text { ues }\end{array}$ & $\begin{array}{c}\text { Varians } \\
(\%)\end{array}$ \\
\hline \multirow{4}{*}{$\begin{array}{l}\text { Fakt } \\
\text { or } 1\end{array}$} & Jujur & 0,848 & \multirow{4}{*}{4,719} & \multirow{4}{*}{$\begin{array}{c}47,193 \\
\%\end{array}$} \\
\hline & Pelatihan & 0,788 & & \\
\hline & $\begin{array}{l}\text { Pendidikan } \\
\text { khusus }\end{array}$ & 0,720 & & \\
\hline & Seminar & 0,552 & & \\
\hline \multirow{6}{*}{$\begin{array}{l}\text { Fakt } \\
\text { or } 2\end{array}$} & Motivasi & 0,894 & \multirow{6}{*}{1,173} & \multirow{6}{*}{$\begin{array}{c}11,730 \\
\%\end{array}$} \\
\hline & Kreatif & 0,680 & & \\
\hline & Praktik & 0,616 & & \\
\hline & $\begin{array}{l}\text { Mata } \\
\text { kuliah }\end{array}$ & 0,600 & & \\
\hline & $\begin{array}{l}\text { Bertanggun } \\
\text { g jawab }\end{array}$ & 0,598 & & \\
\hline & $\begin{array}{l}\text { Pengalama } \\
n\end{array}$ & 0,502 & & \\
\hline
\end{tabular}

Sumber: Hasil Penelitian (Data diolah, 2017)

\section{Penamaan Faktor}

Berdasarkan hasil penelitian dari analisis faktor yang telah dijelaskan di atas, maka dapat ditemukan persamaan matematis dari kedua faktor yaitu sebagai berikut: 
$\mathrm{F} 1=0,848$ Jujur $+0,788$ Pelatihan entrepreneur + 0,720 Pendidikan + 0,552 Seminar entrepreneur

Faktor pertama ini memiliki nilai eigenvalue sebesar 4,719, sehingga dapat disimpulkan bahwa faktor ini merupakan faktor paling dominan dalam memotivasi mahasiswa menjadi entrepreneur Syariah. Faktor 1 ini menerangkan keragaman data sebesar 47,193\%.

Jujur merupakan salah satu karakter yang dimiliki oleh seorang entrepreneur. Jujur yang dimaksud dalam penelitian ini adalah sikap atau sifat seseorang dalam menyatakan sesuatu dengan sesungguhnya atau apa adanya. Karakter jujur disini diwakili oleh beberapa pernyataan dalam kuesioner seperti: Saya terkadang mengatakan yang tidak sebenarnya terjadi, Saya selalu mengungkapkan perasaan dengan apa adanya, Saya selalu mengakui kesalahan dan kekurangan yang dimiliki, dan lain-lain. Sifat jujur sangat penting untuk dimiliki seseorang, seperti dalam firman Allah QS. Al-Ahzab Ayat 70-71 sebagai berikut:

"Hai orang-orang yang beriman, bertakwalah kamu kepada Allah dan Katakanlah Perkataan yang benar,niscaya Allah memperbaiki bagimu amalanamalanmu dan mengampuni bagimu dosadosamu. dan Barangsiapa mentaati Allah dan Rasul-Nya, Maka Sesungguhnya ia telah mendapat kemenangan yang besar". (AlAhzab: 70-71)

Sifat jujur merupakan sifat seorang entrepreneur yang sesuai dengan ajaran Islam, seperti yang dicontohkan oleh Rasulullah SAW dalam menjalankan usahanya (Aprijon, 2013: 10). Oleh sebab itu, sifat jujur sangat penting untuk dimiliki oleh seorang entrepreneur. Dari hasil kuesioner menunjukkan bahwa sebesar $84,8 \%$ sifat jujur menjadi faktor yang mempengaruhi motivasi mahasiswa menjadi entrepreneur syariah.

Pelatihan entrepreneur merupakan salah satu indikator dari variabel pendidikan. Dimana pelatihan entrepreneur yang dimaksud dalam penelitian ini adalah proses pendidikan jangka pendek dengan menggunakan prosedur yang sistematis dengan tujuan peserta pelatihan mampu mempelajari dan memahami mengenai entrepreneur. Dalam penelitian ini, peneliti ingin mengetahui apakah keikutsertaan responden dalam pelatihan entrepreneur mempengaruhi motivasi mahasiswa menjadi entrepreneur syariah. karakter pelatihan diwakili oleh beberapa pernyataan dalam kuesioner yang dianggap akan mendapatkan data mengenai keikutsertaan mahasiswa dalam pelatihan, seperti dalam pernyataan "Saya mempunyai strategi dalam berbisnis setelah mengikuti pelatihan", pernyataan ini akan menunjukan pengaruh dari keikutsertaan pelatihan hingga membuat seseorang memunyai strategi dalam berbisnis. Dari hasil kuesioner menunjukkan sebesar 78,8 \% pelatihan entrepreneur menjadi faktor yang mempengaruhi motivasi mahasiswa menjadi entrepreneur syariah. Hal ini berarti pelatihan entrepreneur merupakan salah satu faktor yang mempengaruhi motivasi mahasiswa menjadi seorang entrepreneur syariah.

Pendidikan khusus merupakan salah satu indikator dari variabel keahlian. Dimana pendidikan khusus disini merupakan pembelajaran ilmu pengetahuan ataupun keterampilan yang dapat membentuk seseorang memiliki keahlian tertentu. Karakter pendidikan khusus diwakili oleh beberapa pernyataan dalam kuesioner seperti: "Saya memiliki keterampilan dalam bidang tertentu 
(misalnya: marketing, accounting, dan lainlain)", dari pernyataan ini peneliti akan mengetahui apakah responden pernah menerima pendidikan khusus dalam suatu bidang, sehingga responden memiliki keahlian pada bidang tertentu. Dari hasil kuesioner menunjukkan sebesar 72,0 \% pendidikan khusus menjadi faktor yang mempengaruhi motivasi mahasiswa menjadi entrepreneur syariah. Hal ini berarti responden yang memiliki keahlian pada bidang tertentu setelah menerima pendidikan khusus.

Seminar merupakan salah satu indikator variabel pendidikan. Dimana seminar yang dimaksud dalam penelitian ini adalah proses pendidikan jangka pendek yang membahas suatu topik yang ditemtukan. Dalam penelitian ini dikhususkan pada seminar berkaitan dengan entrepreneur. Untuk mengetahui apakah responden pernah mengikuti seminar entrepreneur diwakili oleh pernyataan dalam kuesioner seperti "Saya termotivasi menjadi entrepreneur syariah setelah mengikuti seminar entrepreneur", pernyataan ini akan menunjukan apakah semina entrepreneur mempengaruhi motivasi responden menjadi seorang entrepreneur. Dari hasil kuesioner menunjukkan bahwa sebesar $55,2 \%$ seminar menjadi indikator yang mempengaruhi motivasi mahasiswa menjadi entrepreneur syariah.

$F_{2}=0,894$ Motivasi $+0,680$ Kreatif $+0,616$ Praktik + 0,600 Mata kuliah $+0,598$ Bertanggung jawab $+0,502$ Pengalaman

Motivasi merupakan dorongan yang dapat membuat sesorang melakukan suatu perbuatan untu mencapai tujuan tertentu. Motivasi yang dimaksud dalam penelitian ini adalah untuk seberapa besar motivasi yang dimiliki oeh responden dengan mengajuan beberapa pernyataan dalam kuesioner, seperti "Saya ingin menjalankan bisnis sesuai dengan syariat Islam", "Menjadi entrepreneur syariah dapat menciptakan lapangan pekerjaan", dan lain-lain. Dari hasil kuesioner menunjukkan bahwa sebesar 89,4\% motivasi menjadi variabel yang mempengaruhi mahasiswa menjadi seorang entrepreneur syariah. Hal ini berarti mayoritas dari mahasiswa dalam penelitian ini memiliki motivasi yang tinggi untuk menjadi seorang entrepreneur syariah

Kreatif merupakan salah satu indikator dari variabel karakter. Kreatif yang dimaksud dalam penelitian ini adalah kemampuan yang dimiliki seseorang untuk menciptakan sesuatu. Untuk mengetahui ciri-ciri dan karakter kreatif diwakili oleh beberapa pernyataan dalam kuesioner, seperti "Saya termasuk orang yang memiliki banyak ide baru", "Saya senang menemukan cara-cara baru", dan lain lain. Dari hasil kuesioner menunjukkan bahwa sebesar 68,0 \% kreatif yang mempengaruhi motivasi mahasiswa menjadi seorang entrepreneur syariah.

Praktik merupakan salah satu indikator dari variabel pendidikan. Dimana praktik yang dimaksud dalam penelitian ini adalah pelaksanaan secara nyata yang dilakukan seseorang, yaitu praktik melakukan kegiatan entrepreneur maupun yang dilakukan hanya dalam menjalankan tugas kuliah ataupun melakukan praktik dalam menjalankan usaha. Untuk mengetahui apakah responden pernah melakukan praktik entrepreneur peneliti mengajukan beberapa pernyataan yang dianggap akan mendapatkan data dari responden seperti "Saya pernah dan/atau sedang memasarkan produk orang lain", "Saya pernah memasarkan produk yang saya buat sendiri", dan lain-lain. Dari hasil kuesioner menunjukkan bahwa sebesar $61,6 \%$ praktik menjadi indikator yang 
mempengaruhi motivasi mahasiswa menjadi entrepreneur syariah. Hal ini berarti sebesar 61,6\% mahasiswa pernah melaksanakan praktik entrepreneur.

Mata kuliah merupakan salah satu indikator dari variabel pendidikan. Dimana mata kuliah yang dimaksud dalam penelitian ini adalah proses pendidikan selama perkuliahan yang disampaikan dalam jangka waktu tertentu, yaitu mata kuliah yang berkaitan dengan entrepreneur. Untuk mengetahui apakah responden pernah mengambil mata kuliah entrepreneur, maka peneliti pengajukan beberapa pernyataan dalam kuesioner, yaitu "Saya mengetahui dasar-dasar kewirausahaan sebagaimana yang telah dipelajari dalam mata kuliah yang di ambil", "Saya termotivasi menjadi entrepreneur syariah setelah mengikuti mata kuliah yang terkait dengan entrepreneur", dan lain-lain. Dari hasil kuesioner menunjukkan bahwa sebesar $60,0 \%$ mata kuliah menjadi indikator yang mempengaruhi motivasi mahasiswa menjadi entrepreneur syariah.

Bertanggung jawab merupakan salah satu indikator dari karakter. Dimana sifat bertanggung jawab dalam penelitian ini adalah berkewajiban untuk menanggung sesuatu. Dalam hal ini peneliti ingin mengetahui tanggungjawab yang dimiliki responden. Untuk mengetahui ciri-ciri bertanggung jawab diwakili beberapa pernyataan dalam kuesioner, diantaranya "Saya selalu melakukan sesuatu sampai selesai", "Saya selalu menerima resiko dari tindakan yang dilakukan", dan lain-lain. Dari hasil kuesioner menunjukkan sebesar $59,8 \%$ bertanggung jawab menjadi indikator yang mempengaruhi motivasi mahasiswa menjadi entrepreneur syariah.

Pengalaman merupakan salah satu indikator dari keahlian. Pengalaman yang dimaksud dalam penelitian ini adalah sesuatu yang pernah diambil atau pelajaran yang pernah diambil dari sesuatu yang pernah dialami sebelimnya, sehingga dapat membentuk suatu keahlian. Untuk mengetahui pengalaman yang dimiliki responden, peneliti mengajukan beberapa pernyataan dalan kuesioner, diantaranya: "Saya pernah memimpin atau menjadi pengurus dalam suatu organisasi", "Saya termasuk orang yang dapat memanage waktu dengan baik", dan lain-lain. Dari hasil penyebaran kuesioner menunjukkan bahwa sebesar 50,2 \% pengalaman menjadi indikator yang mempengaruhi motivasi mahasiswa menjadi seorang entrepreneur syariah.

Berdasarkan hasil penelitian dari analisis faktor, diperoleh dua faktor yang menjadi acuan dalam motivasi mahasiswa menjadi entrepreneur syariah. Dua faktor dibagi menjadi faktor utama dan faktor pendukung. Faktor utama terdiri dari indikator jujur $(0,848)$, pelatihan $(0,788)$, pendidikan khusus $(0,720)$ dan seminar $(0,552)$. Sedangkan faktor pendorong terdiri dari indikator motivasi $(0,894)$, kreatif $(0,680)$, praktik $(0,616)$, mata kuliah $(0,600)$, bertanggung jawab $(0,598)$ dan pengalaman $(0,502)$.

\section{KESIMPULAN DAN IMPLIKASI}

Setelah penulis melakukan penelitian yang dilakukan pada mahasiswa program studi Ekonomi Islam di Bogor mengenai faktor-faktor yang mempengaruhi motivasi mahasiswa menjadi entrepreneur syariah, terdapat beberapa kesimpulan yang dapat dijelaskan, yaitu:

1. Karakteristik dari responden mahasiswa program studi Ekonomi Islam di Bogor, perempuan lebih mendominasi dibanding laki-laki karena dari jumlah mahasiswa program 
studi Ekonomi Islam di Bogor mahasiswa perempuan lebih banyak dibanding dengan mahasiswa laki-laki. Dan mayoritas mahasiswa yang termotivasi menjadi entrepreneur syariah adalah mahasiswa yang telah menerima pendidikan terkait dengan entrepreneur, baik itu dalam bentuk mata kuliah, pelatihan, seminar maupun praktik melakukan kegiatan entrepreneur.

2. Berdasarkan hasil analisis faktor terdapat faktor-faktor yang menjadi faktor utama dan faktor pendukung dalam mempengaruhi motivasi mahasiswa menjadi entrepreneur syariah. Faktor utama tersebut adalah sikap jujur, pelatihan entrepreneur dan pendidikan khusus. Sedangkan faktor pendukung terdiri dari kreatif, praktik, mata kuliah, bertanggung jawab dan pengalaman. Maka variabel pendidikan, karakter dan keahlian merupakan faktor yang mempengaruhi motivasi mahasiswa menjadi entrepreneur syariah.

Adapun implikasi yang dapat peneliti sampaikan setelah melakukan penelitian pada mahasiswa program studi Ekonomi Islam di Bogor adalah:

1. Perlu adanya wadah untuk mengembangkan motivasi mahasiswa yang memiliki motivasi yang tinggi untuk menjadi seorang entrepreneur syariah agar bisa motivasi yang telah terbentuk bisa menjadi sebuah usaha yang membuat para mahasiswa menjadi entrepreneur syariah. Sehingga setelah lulus, mahasiswa dapat mengembangkan usaha yang telah dijalankannya selama masih kuliah.

2. Mengaktualisasikan motivasi yang dimiliki setiap mahasiswa yang memiliki motivasi untuk menjadi seorang entrepreneur syariah.

3. Diharapkan hasil penelitian ini dapat dijadikan acuan bagi peneliti selanjutnya yang akan meneliti dengan konsep yang sama, agar diperoleh hasil penelitian yang lebih variatif mengenai entrepreneur syariah.

\section{DAFTAR PUSTAKA}

Alma, B., \& Priansa, D. J. 2014. Manajemen Bisnis Syariah. Bandung: Alfabeta, CV .

Amalia, S. 2014. Pengaruh pertumbuhan ekonomi dan inflasi terhadap pengangguran terbuka dan kemiskinan di kota Samarinda. Ekonomika-Bisnis Vol.5 No.2, 173-182.

Antoni. 2014. Muslim Entrepreneur: Membangun Muslim peneur Characteristics dengan pendekatan Knowladge Based Economy. El-Hikam Jurnal Pendidikan dan Kajian KeIslaman Vol VII, No. 2, 325-352.

Aprijon. 2013. Kewirausahaan dan Pandangan Islam. Menara, Vol. 12, No. 1, 1-11.

Aprilianty, E. 2012. Pengaruh Kepibadian wirausaha, pengetahuan kewirausahaan dan lingkungan terhadap minat berwirausaha siswa SMK. Jurnal Pendidikan Vokasi, Vol 2, No 3, 311-324.

Atmaja, A. T., \& Margunani. 2016. Pengaruh pendidikan kewirausahaan dan aktifitas wirausaha terhadap minat berwirausaha mahasiswa Universitas Negeri Semarang. Economic Education Analysis Journal Vol. 5 No. 3, 774-787.

Cahyaningrum, E., Setyawan, Hari, N. S., \& Ainuddi, I. 2013. Karakteristik kewirausahaan dan lingkungan bisnis sebagai faktor penentu pertumbuhan usaha (Studi IKM di Sentra, Kerajinan Rotan Amuntai Kab. Hulu Sungai Utara, 
Provinsi Kalimantan Selatan). Jurnal Administrasi Bisnis, Vol.2, No.1, 1-10.

Darpujianto. 2014. Pengaruh pembelajaran kewirausahaan terhadap motivasi berwirausaha pada mahasiswa STIE dan STMIK 'Asia' Malang. Jurnal JIBEKA Volume 8 No. 1, 21-30.

Endratno, H., \& Widhiandono, H. 2014. Perbandingan Intensi Kewirausahaan Antara Mahasiswa Fakultas Ekonomi dan Mahasiswa Non Fakultas Ekonomi di Universitas Muhammadiyah Purwokerto. ISSN 978-602-14930-2-1, 15.

Fefianti, D., \& Sujianto. 2013. Pendidikan formal, keahlian, pemberian kompensasi dan kinerja pegawai. Jurnal kebijakan Publik, Vol 4, No 1, 105-108.

Frinces, Z. H. 2010. Indonesia, Pentingnya profesi wirausaha di;. Jurnal Ekonomi dan Pendidikan, Volume 7 Nomor 1, 1-24.

Mandiangan, P., \& Yulina, B. 2012. Pengaruh karakteristik wirausaha dan sikap wirausaha terhadap perilaku kewirausahaan (Studi kasus pada mahasiswa Politeknik Negeri Sriwijaya). Jurnal Eksistansi

Munawar, W. 2016. Implementasi sistem manajemen mutu ISO 9001:2008 di Badan Amil Zakat Nasional. Jurnal Syarikah ISSN 2442-4420 Volume 2 Nomor 1, 154.
Nuriasari, S. 2013. Menumbuhkan jiwa kewirausahaan di Perguruan Tinggi. Jurnal Adzkiya Vol. 1 No. 2 , 1-18.

Safitri, A. R., \& Rustiaba, A. 2016. Pengaruh pendidikan kewirausahaan dan kepribadian terhadap minat berwirausaha siswa jurusan pemasaran. Economic Education Analysis Journal Vol 5 No 3, 886-899.

Santoso, N. A. 2014. Kajian Karakteristik Kewirausahan Dan Perusahaan Terhadap Keerhasilan Usaha Kecil. Jurnal Arthavidya Vol. 16 No. 1, 1-21.

Saputra, A. D., \& Susena. 2013. Kontribusi mata kuliahkewirausahaan dalam menumbuhkan jiwa entrepreneurship yang beretika pada mahasiswa prodi PPKn FKIP UAD Yogyakarta. Jurnal Citizenship, Vol. 2 No. 1, 41-48.

Setyaningsih, I. 2014. Analisis faktor penghambat keberhasilan mahasiswa menjadi entrepreneur. Jurnal seminar nasional IENACO ISSN: 2337-4349, 535541.

Susilaningsih. 2015. Pendidikan kewirausahaan di Perguruan Tinggi: Pentingkah untuk semua profesi? Jurnal Economia, Vol 11, No 1, 1-9.

Sugiono. 2013. Metode Penelitian Kombinasi (Mixed Methode). Bandung: Alfabeta.

Tama, A. A. 2010. Analisis faktor-faktor yang memotivasi mahasisawa berkeinginan menjadi entrepreneur. Skripisi, 19-31. 


\section{Ucapan Terima Kasih}

Dewan Redaksi serta Redaksi Pelaksana Jurnal Syarikah mengucapkan terima kasih dan penghargaan setinggi-tingginya kepada para pakar yang telah berperan sebagai mitra bebestari pada penerbitan Jurnal Syarikah Volume 3 Nomor 1 Juni Tahun 2017.

$$
\text { Dr. Nurul Huda, M.Si }
$$

Semoga kerjasama yang baik dapat terus berlangsung di masa-masa yang akan datang untuk lebih meningkatkan kualitas Jurnal Syarikah. 


\title{
PANDUAN BAGI PENULIS JURNAL SYARIKAH: JURNAL EKONOMI ISLAM
}

\author{
Pemutakhiran Juni 2017
}

\section{RUANG LINGKUP}

Jurnal Syarikah: Jurnal Ekonomi Islam mendorong pengembangkan ilmu pengetahuan dan teknologi dalam bidang Ekonomi Islam melalui penerbitan karya ilmiah berbasis hasil penelitian (orisinal).

\section{JENIS NASKAH}

Jenis naskah yang dipublikasikan adalah naskah orisinal hasil penelitian yang belum pernah dipublikasikan atau tidak sedang dalam proses publikasi oleh media publikasi lain dan terbebas dari plagiarisme. Bahasa publikasi adalah bahasa Indonesia atau bahasa Inggris. Setiap naskah yang masuk ke dewan redaksi akan menjalani proses peer-review.

Naskah hasil penelitian harus didasarkan atas data hasil penelitian orisinal yang belum dipublikasikan dan dianalisis menggunakan metode statistik. Naskah hasil penelitian yang disajikan secara deskriptif tanpa rancangan penelitian yang dikontrol oleh peneliti, naskah hasil penelitian yang hanya berupa pengulangan (replikasi) dari hasil penelitian yang telah dipublikasikan, misalnya hanya kondisi geografisnya yang berbeda, tidak akan dipertimbangkan untuk dipublikasikan. Naskah bernomor seri tidak dapat diterima, kecuali disampaikan dan disajikan pada waktu yang bersamaan.

\section{PENGIRIMAN NASKAH}

Naskah yang diajukan ditujukan ke Pimpinan Dewan Redaksi Jurnal Syarikah, melalui e-mail ke tuti.kurnia@unida.ac.id. Naskah dimaksud harus dilengkapi dengan Surat Pernyataan Orisinalitas dan Pemindahan Hak Publikasi yang ditandatangi oleh semua penulis.

\section{KONVENSI DAN KETAATASASAN}

Naskah harus ditulis dengan tema font Time New Roman 12, spasi ganda, batas tepi $2,5 \mathrm{~cm}$, halaman berukuran A4, menggunakan program microsoft office word. Naskah ditulis tidak lebih dari 7.500 kata berdasarkan urutan bagian berikut:

1) Judul (Title): JUDUL berbahasa Indonesia dan Inggris, Nama Penulis, Alamat Penulis, Penulis untuk Korespondensi, dan Judul Singkat (Running Head).

2) Tajuk Utama (main section headings): ABSTRACT, ABSTRAK, PENDAHULUAN, MATERI DAN METODE, HASIL, PEMBAHASAN, KESIMPULAN DAN IMPLIKASI, UCAPAN TERIMA KASIH, DAFTAR PUSTAKA.

3) Lampiran: Tabel, Grafik, dan Gambar.
Judul naskah harus berhuruf tebal dan kapital, ditulis pada bagian tengah dari baris tersendiri. Tajuk dan subtajuk ditulis pada baris tersendiri, mulai dari batas tepi kiri badan teks. Tajuk berhuruf tebal dan kapital. Subtajuk berhuruf tebal dan huruf kapitalnya hanya pada awal kata. Jarak antara tajuk dan subtajuk adalah 10 point (pt) sedangkan jarak antara tajuk atau subtajuk dan badan teks adalah 6 pt. Pembeda paragraf dimulai pada paragraf kedua setelah tajuk atau subtajuk dan dicirikan oleh baris pertamanya yang berjarak $0,5 \mathrm{~cm}$ dari batas tepi kiri badan teks.

Naskah yang terlalu panjang atau terlalu pendek akan dikembalikan kepada penulis. Sebagai pedoman, 7.500 kata setara dengan 34 halaman ukuran A4, yang ditulis dengan tema font Time New Roman 12, spasi ganda, marjin $2,5 \mathrm{~cm}$ dari semua tepi halaman. Judul tidak lebih dari 12 kata, Judul Singkat tidak lebih dari 50 karakter, Abstract dan Abstrak masing-masing tidak lebih dari 250 kata, key words dan kata kunci masing-masing 5 kata, dan Pendahuluan tidak lebih dari 500 kata.

\section{Judul}

Judul harus ringkas dan padat informasi, tidak memuat kata singkatan, dan memuat hal-hal berikut:

a) membangkitkan minat bagi pembaca yang memindai jurnal atau daftar judul jurnal.

b) Menyediakan informasi yang cukup bagi pembaca untuk menilai relevansi suatu naskah dengan minatnya

c) Memasukkan kata kunci atau frasa yang dapat digunakan dalam mengindeks dan menarik informasi tentang penelitian yang dilakukan.

d) Menghindari kata-kata yang tidak penting, seperti "suatu studi kasus ...." atau "suatu tinjauan empiris tentang ....". Hal-hal tersebut lebih tepat ditulis pada subbagian Materi dan Metode.

e) Tidak boleh memuat kata tempat, seperti “.... di Bogor"

\section{Nama dan Alamat Penulis}

Nama dan alamat penulis harus disajikan seperti contoh berikut:

G. PraditinKa ${ }^{1, a}$ dan W. munawar ${ }^{2}$

${ }^{1}$ Lembaga Penelitian dan Pengembangan Universitas Djuanda, Jl. Tol Ciawi Kotak Pos 35 Bogor 16720.

${ }^{2}$ Program Studi Ekonomi Islam Fakultas Ekonomi Islam Universitas Djuanda, Jl. Tol Ciawi No. 1 Kotak Pos 35 Bogor 16720.

aKorespondensi: Tuti Kurnia. Telepon: 0818106472; E-mail: tuti.kurnia@unida.ac.id 


\section{Judul Singkat (running head)}

Penulis harus menuliskan judul singkat tidak lebih dari 50 karakter termasuk ketukan kosong.

\section{Abstract dan Abstrak}

Abstract ditulis dalam bahasa Inggris baku secara konsisten (American English atau British English). Abstrak ditulis dalam bahasa Indonesia yang baik dan benar, menggunakan kata-kata baku. Baik abstract maupun abstrak dibuat dalam satu paragraf utuh tanpa ada acuan pustaka atau perujuk tabel dan/atau gambar, tidak lebih dari 250 kata. Isinya harus memuat masalah penting yang akan dipecahkan, tujuan, metode, hasil, kesimpulan, dan tidak boleh terlalu padat dengan angka-angka. Penyingkatan kata tidak diperkenankan kecuali kata dimaksud akan digunakan lebih dari satu kali..

\section{Keywords dan Kata Kunci}

Keywords (berbahasa Ingris) dan Kata kunci (berbahasa Indonesia), masing-masing tidak lebih dari lima kata dan sebaiknya tidak sama dengan kata-kata yang terdapat dalam judul naskah. Jika tidak memadai, dewan redaksi akan mengubahnya atas persetujuan penulis.

\section{Pendahuluan}

Pendahuluan yang ditulis tidak lebih dari 500 kata, harus menjelaskan isu-isu mutakhir yang mengarah pada pentingnya penelitian yang dilakukan, tujuan penelitian dinyatakan dengan jelas, dan menuliskan state of the art dari topik penelitiannya sehingga gambaran utama penelitiannya menjadi jelas bagi para pembaca. Namun, acuan pustaka dalam pendahuluan harus dibatasi karena bukan merupakan pembahasan awal.

\section{Materi dan Metode}

Materi dan metode penelitian harus dijelaskan secara terperinci pada bagian ini sehingga memungkinkan bagi peneliti lain untuk mengulang penelitian ini. Materi atau bahan yang digunakan tidak diperinci secara terpisah, melainkan harus terintegrasi dengan prosedur penelitian. Misalnya, .."responden diminta mengisi daftar pertanyaan menggunakan pensil 2B dan memilih satu dari tiga poster yang diperlihatkan oleh peneliti...", tidak perlu memerincinya seperti berikut: " Materi penelitian terdiri atas: daftar pertanyaan, pensil 2B, dan poster. Jika penelitian menggunakan produk berpemilik (seperti paten) untuk pembanding, produk dimaksud harus dituliskan dalam nama yang baku atau dituliskan merk dagangnya di dalam tanda kurung jika dianggap membantu memperjelas pemahaman pembaca, namun syaratnya harus mendapat izin tertulis dari pemilik produk dimaksud sebelum dipublikasikan. Model, tipe, merk, dan produsen peralatan yang digunakan dalam penelitian harus dijelaskan. Metode dan model analisis statistik harus jelas sehingga memungkinkan bagi peneliti lain untuk melakukan pengulangan.

Sistematika penulisannya diurutkan sebagai berikut: materi, rancangan percobaan dan perlakuan, prosedur pelaksanaan penelitian, analisis laboratorium, dan analisis statistik. Sistematika ini tidak kaku, dapat disesuaikan dengan ciri bidang keilmuan. Misalnya, untuk penelitian agribisnis yang tidak ada analisis laboratoriumnya, tidak perlu ada analisis laboratorium. Sebaliknya, subbagian lainnya dapat ditambahkan sesuai kebutuhan.

\section{Hasil dan Pembahasan}

Hasil penelitian, termasuk hasil analisis statistiknya dipaparkan secara terperinci dalam bagian ini. Ilustrasi, jika diperlukan dapat disajikan dalam bentuk tabel dan/atau gambar. Tabel dan gambar harus sederhana, informatif, mudah dipahami, dan mandiri, dalam arti tabel atau gambar dimaksud harus bisa menjelaskan kepada pembaca sehingga pembaca tidak harus membaca tulisannya untuk memahaminya. Hal yang sudah dijelaskan dalam tabel atau gambar tidak perlu diulang dalam tulisan. Tabel dan gambar dimuat pada halaman terpisah darik teks.

Hasil penelitian selanjutnya dibahas dengan cara membandingkannya dengan hasil penelitian pada topik serupa dari peneliti sebelumnya untuk mengungkap keajegannya (konsistensinya) apakah konsisten (sama) atau berbeda, lalu jelaskan alasan ilmiahnya atas hasil dimaksud secara lugas dan tuntas sehingga memperjelas posisi hasil penelitiannya. Selanjutnya, temuan hasil penelitian diungkapkan disertai kelebihan dan kelemahannya, jika ada. Ungkapan temuan hasil penelitian ini akan mempermudah dalam menyimpulkan hasil penelitian.

Data rataan perlakuan harus ditulis dengan galat bakunya (standard errors). Tingkat signifikansi statistik dapat dinyatakan dalam $\mathrm{P}<0,05, \mathrm{P}<0,01$, dan $\mathrm{P}<0,001$. Khusus pada tabel, tingkat signifikansi dimaksud, berturut-turut dapat ditulis dengan *, **, dan ${ }^{* * *}$ sedangkan pada tabel dan grafik, perbedaan antarperlakuan dapat ditunjukkan dengan huruf $a, b$ untuk $\mathrm{P}<0,05$ dan $\mathrm{A}$, B untuk $\mathrm{P}<0,01$.

\section{Kesimpulan dan Implikasi}

Kesimpulan memuat temuan hasil penelitian yang mencerminkan kebaruan, keorisinilan, kepioneran, keuniversalan, dan kontribusi ilmiah dalam pengembangan ilmu pengetahuan dan teknologi. Pernyataan dalam simpulan terbebas dari frasa atau istilah statistik, seperti " ..berpengaruh nyata $(\mathrm{P}<0,05) "$

Penulis harus menjelaskan implikasi hasil penelitiannya dalam pengembangan keilmuan, dan dampaknya terhadap lingkungan, sosial, budaya, 
ekonomi, politik, dan/atau hukum. Implikasi dipaparkan dalam bahasa yang sederhana agar pembaca noncendekia dapat memahaminya dengan mudah.

\section{Ucapan Terima Kasih}

Ucapan terima kasih hanya wajib ditulis jika penelitian didukung (biaya, sarana, tenaga) oleh instansi atau individu, atau penelaah sejawat jika naskahnya ditelaah sebelum dipublikasikan.

\section{Daftar Pustaka}

Penulis bertanggung jawab atas kebenaran semua sumber pustaka yang dirujuk dan dituliskan dalam Daftar Pustaka dan yang diacu dalam teks. Sumber pustaka sangat dianjurkan menggunakan terbitan terbaru (10 tahun terakhir), dan disajikan secara alfabet dan dituliskan menurut format nama tahun. Beberapa format dan contoh penulisannya antara lain:

Naskah jurnal atau abstrak. Format: Nama Penulis. Tahun. Judul. Nama Jurnal. Volume: Halaman. Contoh:

Rahmawati R, G Praditina dan RA Munjin. 2009. Model pelayanan rumah sakit berbasis karakteristik sosial ekonomi masyarakat untuk meningkatkan kepuasan pasien. Jurnal Humaniora. 1(1): 18-29.

Buku. Format: Nama Penulis atau Nama Editor atau Nama Lembaga. Tahun. Judul. Edisi, Nama Penerbit, Tempat Penerbitan. Contoh:

Roestamy M. 2011. Konsep-konsep hukum kepemilikan properti bagi asing (dihubungkan dengan hukum pertanahan). Edisi pertama. PT. Alumni. Bandung.

Bab buku atau proseding. Format: Nama Penulis. Tahun. Judul. Dalam: Judul buku atau proseding (Nama Editor). Volume: Halaman. Nama Penerbit, Tempat Penerbitan. Contoh:

Goulet D. 2000. Ethics, culture and development: livestock, poverty and quality of rural life. In: Livestock, ethics and quality of life (eds. Hodges, John and Han, In K). 131-154. CABI Publishing, New York, NY 10016, USA.

Laporan pada pertemuan ilmiah (konferensi, workshop, dll) yang tidak tercakup dalam buku atau proseding. Format: Nama Penulis. Tahun. Judul. Judul atau Nama Pertemuan Ilmiah, Tempat Pertemuan. Jumlah halaman. Contoh:

Jalal F. 2011. Tantangan dan peluang pendidikan di Indonesia. Orasi Ilmiah. Wisuda XXVI Sarjana dan Pascasarjana Universitas Djuanda, Bogor. 16 hal.

Tesis atau Disertasi. Format: Nama Penulis. Tahun. Judul. Tesis atau Disertasi. Nama Perguruan Tinggi, Tempat Perguruan Tinggi. Contoh:

Roestamy M. 2008. Kepastian hukum atas kepemilikan rumah dan bangunan gedung oleh investor asing dikaitkan dengan asas nasionalitas dalam sistem hukum pertanahan Indonesia. Disertasi. Program Studi Doktor Ilmu Hukum Fakultas Hukum Universitas Padjadjaran, Bandung.

Karya Ilmiah Lepas yang dimuat pada Website. Karya ilmiah lepas yang dimuat pada website hanya dapat digunakan jika literatur standard lainnya tidak tersedia. Format: Nama Penulis. Tahun. Judul. Diunduh tanggal-bulan-tahun dari http://.... Contoh:

Bryant P. 1999. Biodiversity and Conservation. Retrieved October 4, 1999 from http://darwin bio.uci.edu/ sustain/bio65/Titlpage.htm

\section{Penulisan Nama Penulis yang Diacu pada Teks}

Nama penulis yang diacu di dalam teks tidak diperkenankan menggunakan footnote. Jika jumlah penulis kurang dari tiga nama penulis ditulis semua, jika jumlah penulis tidak kurang dari tiga, hanya penulis utama yang ditulis dan diikuti dengan et al. Contoh: Syamsah (2010) menyimpulkan bahwa pajak dan zakat memiliki hubungan reduktif dan deduktabel. Parameter kualitas layanan puskesmas secara simultan mempengaruhi kepuasan pasien (Yuningsih dan Maulana 2010). Kekurangan dari kualitas pelayanan rumah sakit dapat diatasi apabila rumah sakit memperhatikan karakteristik pasien (Rahmawati et al. 2010). Tingkat kepuasan pasien menjadi indikator penting dalam mengukur kualitas pelayanan kesehatan (Yuningsih dan Maulana 2010; Rahmawati et al. 2010).

\section{Tabel}

Tabel harus dibuat sesederhana dan sesedikit mungkin, namun sekurang-kurangnya harus memuat dua baris data. Jika hanya ada satu baris data, maka penyajiannya harus menggunakan grafik. Garis horisontal tabel hanya boleh untuk mencirikan batas baris teratas (heading) dan garis terbawah dari badan tabel, sedangkan garis-garis kolom tabel tidak diperkenankan. Tabel dibuat dengan menggunakan fungsi tabel dalam program microsoft office word. Judul tabel harus ringkas, jelas, dan informatif, diberi nomor urut angka arab, huruf kapital hanya pada huruf pertama judul tabel kecuali beberapa nama diri, dan ditempatkan di atas badan tabel. Lazimnya, peubah disajikan dalam baris dan perlakuan disajikan pada kolom tabel. Keterangan tabel disajikan di bagian bawah badan tabel tanpa menuliskan kata keterangan. Di dalam teks, nomor tabel harus dirujuk, misalnya: kepribadian dalam pandangan Islam merupakan integrasi sistem kalbu, akal, dan nafsu (Tabel 1). Judul tabel, tabel dan keterangan tabel disajikan pada halaman tersendiri setelah Daftar Pustaka. Lebar tabel $80 \mathrm{~mm}$ atau $160 \mathrm{~mm}$. Jangan menyisipkan tabel pada bagian teks. Contoh Tabel lebar $80 \mathrm{~mm}$ : 
Table 1 Persentase distribusi daya fitrah nafsani dalam pembentukan kepribadian

\begin{tabular}{lccc}
\hline \multirow{2}{*}{$\begin{array}{l}\text { Daya fitrah } \\
\text { nafsani }\end{array}$} & \multicolumn{3}{c}{ Tingkat kepribadian (\%) } \\
\cline { 2 - 4 } & Muthmainnah & Lawwamah & Ammarah \\
\hline Kalbu & 55 & 30 & 15 \\
Akal & 30 & 40 & 30 \\
Nafsu & 15 & 30 & 55 \\
\hline
\end{tabular}

Format tabel diubahsuai dari Sulaiman H (2010) tanpa mengubah substansi.

\section{Gambar dan Grafik}

Gambar dan grafik dibuat dalam format JPEG dan hanya diperbolehkan jika data hasil penelitian tidak dapat disajikan dalam bentuk tabel. Grafik yang dibuat dengan program microsoft office excel harus diubahsuiakan menjadi format JPEG dengan kualitas gambar yang layak cetak. Ukuran lebar gambar adalah $80 \mathrm{~mm}$ atau $160 \mathrm{~mm}$. Judul gambar harus ringkas, jelas, dan informatif, diberi nomor urut angka arab, huruf kapital hanya pada huruf pertama judul gambar kecuali beberapa nama diri, dan ditempatkan di bagian bawah gambar. Contoh gambar berformat JPEG lebar $80 \mathrm{~mm}$ (Gambar 1).

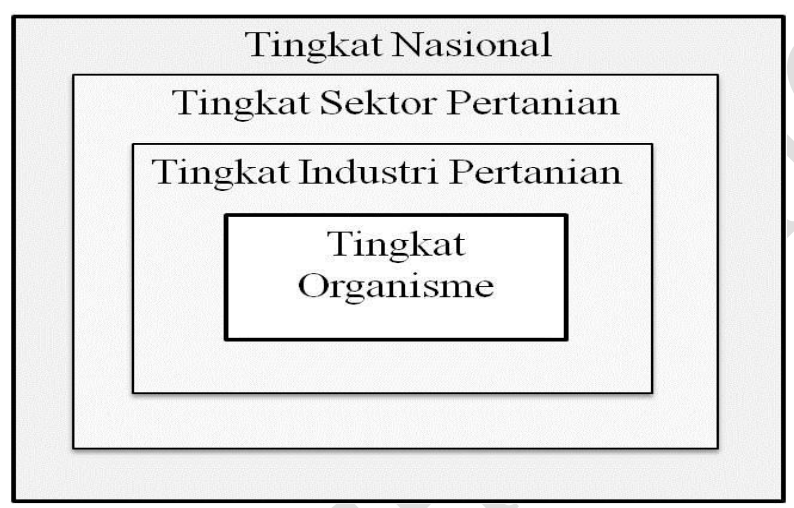

Gambar 1 Empat tingkat domain untuk menghadapi agroterorisme (ubahsuai dari Kohnen 2000).
Keterangan gambar ditulis setelah dan merupakan bagian integral dari judul gambar. Gambar dan judul gambar disajikan pada halaman tersendiri setelah halaman tabel. Di dalam teks, seluruh nomor gambar harus dirujuk secara berurutan seperti nomor tabel. Gambar dicetak hitam putih dan jika penulis menghendaki gambar berwarna, maka biaya pencetakan menjadi tanggung jawab penulis.

\section{Cetak Lepas}

Penulis yang naskahnya telah dipublikasikan akan mendapatkan satu Jurnal Humaniora dan dua eksemplar cetak lepas (reprint) artikelnya. Penulis yang ingin menambah jumlah jurnal dan cetak lepasnya dapat memesannya ke Dewan Redaksi melalui telefon atau email. Berikut ini adalah daftar harga Jurnal Humaniora dan cetak lepasnya, belum termasuk ongkos kirim.

Daftar harga Jurnal Humaniora dan cetak lepasnya

\begin{tabular}{lll}
\hline Jumlah & $\begin{array}{l}\text { Jurnal Syarikah } \\
\text { (Rp/eksemplar) }\end{array}$ & $\begin{array}{l}\text { Cetak lepasnya*) } \\
\text { (Rp/eksemplar) }\end{array}$ \\
\hline $1-5$ & 75.000 & 30.000 \\
6 atau lebih & 60.000 & 25.000 \\
\hline
\end{tabular}

${ }^{*}{ }^{6}$ pemesanan minimal 5 eksemplar. 


\section{SURAT PERNYATAAN ORISINALITAS ${ }^{1}$}

Kepada

\section{Dewan Editor Jurnal Syarikah}

Program Studi Ekonomi Islam Fakultas Ekonomi islam

Universitas Djuanda Bogor

Bersama ini kami mengajukan naskah,

\section{Judul :}

Penulis:

\begin{tabular}{|c|c|c|c|c|}
\hline No & $\begin{array}{c}\text { Penulis lengkap dengan } \\
\text { gelar akademik }\end{array}$ & Nama dan Alamat Institusi, email & $\begin{array}{l}\text { Tanda } \\
\text { Tangan }\end{array}$ & Tanggal \\
\hline
\end{tabular}

1

2

3

untuk dipublikasikan pada Jurnal Syarikah. Kami menyatakan bahwa naskah dimaksud adalah naskah orisinal hasil penelitian kami yang belum pernah dipublikasikan, tidak sedang dalam proses publikasi oleh media publikasi lainnya, tidak akan diajukan ke media publikasi lainnya selama dalam proses penelaahan (review) kecuali jika kami menarik secara resmi naskah dimaksud dari Dewan Redaksi Jurnal Syarikah, terbebas dari plagiarisme, dan kami bertanggung jawab atas seluruh substansi naskah berjudul tersebut di atas yang kami tulis.

Nama penulis untuk korespondensi:

Telepon/(hanya digunakan untuk keperluan korespondensi)

Email: (untuk keperluan korespondensi dan akan dicantumkan pada artikel yang

dipublikasikan)

Terima kasih atas perhatian dan kerjasamanya.

Tanggal:

Penulis:

Tanda tangan:

\footnotetext{
${ }^{1}$ Dikirim ke Dewan Redaksi Jurnal Syarikah, Program Studi Ekonomi Islam Fakultas Ekonomi Islam Universitas Djuanda Bogor, Gedung B Lantai IV Jl Tol Ciawi No. 1 Kotak Pos 35 Ciawi Bogor 16720, difaksimilikan ke 02518240985, dan hasil scanning-nya diemailkan ke Jurnal.Syarikah@unida.ac.id.
} 


\section{SURAT PERNYATAAN PEMINDAHAN HAK CIPTA ${ }^{2}$}

Yang bertanda tangan di bawah ini adalah penulis naskah yang berjudul:

yang diajukan untuk dipublikasikan pada Jurnal Syarikah: Jurnal Ekonomi Islam ISSN 2442-4420 menyatakan bahwa:

Kami bersedia memindahkan hak publikasi, distribusi, reproduksi, dan menjual naskah kamiyang berjudul tersebut di atas sebagai bagian dari Jurnal Syarikah kepada Dewan Redaksi Jurnal Syarikah ISSN 2442-4420

Demikian surat pernyataan ini saya buat dengan sadar, penuh rasa tanggung jawab, dan tanpa paksaan dari pihak mana pun!

\begin{tabular}{llcc}
\hline No & $\begin{array}{l}\text { Nama Penulis (lengkap } \\
\text { dengan gelar akademik) }\end{array}$
\end{tabular}$\quad$ Nama dan Alamat Institusi, email $\begin{gathered}\text { Tanda } \\
\text { Tangan }\end{gathered}$ Tanggal




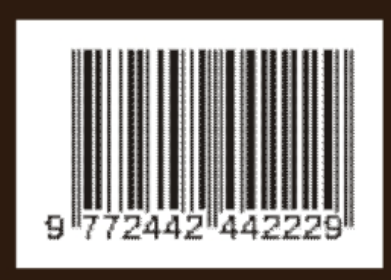

